\title{
Croatian Language
}

National Cancer Institute

\section{Source}

National Cancer Institute. Croatian Language. NCI Thesaurus. Code C153950.

The standardized variety of the Serbo-Croatian language used by Croats, principally in Croatia, Bosnia and Herzegovina. 